\title{
Incorporating Indigenous values with 'Western' conservation values in sustainable biodiversity management
}

\author{
A.J.J. Lynch, D.G. Fell and S. McIntyre-Tamwoy *
}

B iodiversity management in Australia is underlain by legislative mechanisms such as the Environment Protection and Biodiversity Conservation Act 1999 (Cwlth) and policies such as the national Strategy for the Conservation of Australia's Biological Diversity and the international Convention on Biological Diversity. While these policy directives encompass a range of values and components of 'biodiversity', on-ground planning and development assessments often focus only on threatened species and ecosystems as defined in state and national legislation. In regions such as northern Cape York Peninsula, which is managed by the resident Aboriginal and Torres Strait Islander communities as Deed of Grant in Trust (DOGIT), planning for biodiversity management needs to acknowledge the high cultural values of such areas and to encompass Indigenous values and perspectives. A recent study assessed the significant species and habitats of the greater Lockerbie Scrub - the northernmost extent of rainforest in Australia and a region with high species and ecosystem diversity. While it is acknowledged that research into the cultural values of the plant species is preliminary, the minimal overlap between lists of flora from Western (i.e. under legislative mechanisms) and Traditional Owner perspectives suggests that cultural differences in values and perceptions may result in differing conservation management priorities. A more holistic, integrative approach to local and national biodiversity management planning could accommodate multiple perspectives and enable greater environmental and socio-cultural sustainability.

Keywords: Indigenous, Aboriginal, Gudang, biodiversity, conservation, environmental management, cultural values

\footnotetext{
* Jasmyn Lynch is with the Centre for Environmental Management, School of Science and Engineering, University of Ballarat, PO Box 663, Ballarat Vic 3353; David Fell is at PO Box 337, Alstonville NSW 2477; and Susan McIntyre-Tamwoy is with the School of Arts and Social Sciences, James Cook University, PO Box 6811, Cairns Qld 4870. Email: j.lynch@ballarat.edu.au.
}

In this United Nation's declared Year of Biodiversity, it is important to take stock of and reassess commitments made at the 1992 Earth Summit in Rio and the subsequent ratification in 1993 of the Convention on Biological Diversity (CBD). These events were benchmarks in formalising the place of biological conservation globally and for instituting the term 'biodiversity' in the public, governmental and scientific sectors, and in international attitudes to conservation, environmental management and sustainable development. The close and traditional dependence of many Indigenous communities on biological resources is also recognised in the $\mathrm{CBD}$, along with the need to respect, preserve and maintain traditional knowledge (see SCBD 2005, pp. 5-8).

The Australian commitment as a signatory to the CBD was directly associated with the development of biodiversity-related national policy (e.g. the Intergovernmental Agreement on the Environment 1992'; the National Strategy for Ecologically Sustainable Development 1992² the National Forest Policy Statement (CoA 1992); the Strategy for the Conservation of Australia's Biological Diversity (DEST 1996) and legislation (various Acts and regulations encompassing conservation of species, ecosystems, and national and cultural assets, which later were amalgamated under the Commonwealth's Environment Protection and Biodiversity Conservation Act 1999, EPBC Act). Similar policy and legislation mechanisms have been enacted internationally, such as the Endangered Species Act 1973 in the United States, the UK Biodiversity Action Plan, the Birds Directive of 1979 and Habitats Directive of 1992, which protect endangered species in European Union member states (McLean et al. 1999). Evaluation of threats to species underlies decisions globally about species conservation listing and prioritisation, such as under the International Union for Conservation of Nature Red List categories of extinction risk (IUCN 2001).

\footnotetext{
${ }^{1}$ See http://www.environment.gov.au/about/esd/publications/igae/index.html (viewed 26 September 2010).

${ }^{2}$ See http://www.environment.gov.au/about/esd/publications/strategy/ index.html (viewed 26 September 2010).
} 
The role of Indigenous communities in Australian environmental management has developed inconsistently between regions, but Indigenous land and sea management activities in northern Australia have proliferated since the mid-1980s (Hill et al. 2008). Indigenous Australian communities are involved in biodiversity and cultural heritage management through formalised land and sea management programs, including the Indigenous Protected Area program. They have responsibility through land claims under the Native Title Act 1993 (Cwlth) for 12.1 per cent of the country (National Native Title Tribunal 2010) ${ }^{3}$, predominantly in remote areas (Altman et al. 2009) with limited alternatives for effective land management arrangements. It should be noted, however, that, for some IPAs, cultural heritage is considered a primary value with biodiversity values as secondary (see DEWR 2007).

Nevertheless, and despite the acknowledgement of its importance in the CBD, Indigenous Traditional Ecological Knowledge (TEK) is frequently viewed as inferior to 'Western' scientific approaches - as being intuitive, informal, less reliable and less accessible - and its use remains elusive (Huntington 2000; Smallacombe et al. 2007). In contrast, scientific approaches to conservation have been criticised for being reductionist and relying on objectification and specificity, while ignoring social factors, long timescales and differing perspectives (Strang 1997, p. 266; Jackson 2005; Rotarangi \& Russell 2009) - essentially hyper-focusing on some aspects while neglecting the broader interconnectedness and complexity of ecosystems and of the human - nature relationship.

However, there is an increasing call to recognise and integrate TEK and Western scientific knowledge into environmental management (Berkes et al. 2000; Huntington 2000; Ross \& Pickering 2002). Western conservation management approaches and Indigenous environmental perspectives have been viewed as in conflict, but an alternative is to recognise the multiplicity of logics and practices underlying different knowledge systems and to reframe the debate as a science and traditional knowledge dialogue and partnership with coproduction of complementary knowledge for problemsolving (Agrawal 1995; Berkes 2009). There are substantial heterogeneities among Indigenous knowledge systems and substantial similarities across the artificial Indigenous - Western knowledge divide (Agrawal 1995).
Both Indigenous and Western approaches to environmental management could be perceived as resource use frameworks but focused on different environmental aspects and timescales. Jackson (2005, p. 138) argued against this on the basis that Indigenous values are not purely utilitarian but related to broader humanitarian 'notions of sociality, sacredness, identity and life-giving'. However, Strang (1997) claimed that Aboriginal management was highly practical, well organised, and coupled regular resource use with management of the physical environment (including the use of spiritual increase rituals) to maximise and control resource availability and stability. Places were valued according to their resources, which is consistent with Western perspectives.

Further, both Indigenous and Western environmental management approaches have impacted on landscapes and biotic assemblages. Lewis (1989) argued that Aborigines and other foraging societies had varied and pronounced effects on most world environments, with Aboriginal setting of habitat fires as particularly ecologically significant in Australia. Russell-Smith et al. (1997) supported that many elements of traditional burning patterns - including its ordered, directed manner - were common to pre-contact Aboriginal groups in coastal northern Australia. Although describing the impact of Aboriginal burning on biodiversity and on species extinctions and diversification as 'complex' and 'contentious', Bowman (1998) acknowledged that it must have influenced vegetation structure and species ranges, and may have caused the extinction of some species with fire-sensitive habitats, particularly during periods of climatic stress. Lack of burning by Europeans, however, may have caused severe declines in small-to-mediumsized mammal populations, vegetation changes, and range contractions in conifers and some monsoon rainforest trees (Bowman 1998; Russell Smith et al. 2004).

Since European settlement, land clearance has exceeded ecological limits across most of the intensive land-use zone of Australia, and significantly compromised broadscale landscape functions (Beeton \& McGrath 2009). There are now over 2800 threatened ecosystems in Australia (Cork et al. 2006), many of Australia's mammal species occur over less than 20 per cent of their original range, six per cent of marsupials and 14 per cent of rodents extant 200 years ago are extinct, while 76

\footnotetext{
${ }^{3}$ Large areas of freehold land (5.7 million hectares) are also owned by Aboriginal corporations in urban, rural and remote Australia (in contrast to land claimed under Native Title) and granted through the Commonwealth's Indigenous Land Corporation (Indigenous Land Corporation 2010). In addition, in Queensland, over 1.7 million hectares of land has been transferred to land trusts with over 2 million hectares of land available to be transferred to Aboriginal and Torres Strait Islander bodies under the Aboriginal Land Act 1991 (Qld) and Torres Strait Islander Land Act 1991 (Qld) (DERM 2010).
} 
plant species (1.5 per cent) are extinct and 1260 plant species (6.5 per cent) are threatened (Briggs \& Leigh 1996; Johnson 2006; Chapman 2009).

Compounding these declines of biota and landscape functionality is the global threat of anthropogenic climate change. Climate change is expected to exacerbate existing stresses on environments, ecosystems and human population stability, by compounding threats such as increasing resource use intensity, poor farming or pastoral practices, invasive species and inappropriate fire regimes (Steffen et al. 2010). Apart from the climatic impacts, climate change is likely to enhance disturbance regimes (e.g. fire and invasive species), change local water availability and evapotranspiration regimes, and cause species migrations and assemblage shifts; the latter already evident in many regions (Easterling et al. 2000; McCarty 2001). The MEA (2005) has predicted massive extinctions for this century, with losses of about 1000 times greater than background levels.

Thus, it is evident that conservation approaches need urgent supplementation. The CBD clearly identified all biodiversity components as conservation targets. Nevertheless, and despite national and international conservation mechanisms, declines in biodiversity including ecosystem and species abundance, extent and condition - have continued globally (Butchart et al. 2010). Further, environmental pressures are increasing but management responses are slowing (Butchart et al. 2010). Indeed, the financial cost of the loss of global biodiversity may be as much as $€ 14$ trillion (seven per cent of global GDP) by 2050 (Natural England 2010).

To encapsulate the complexity and functional aspects of biodiversity at the landscape and regional scales and to address the compounding effects of environmental degradation and climate change will require innovative approaches from multiple perspectives and the urgent development of a comprehensive, hierarchical, integrated systems approach to biodiversity conservation. In addition, given the widespread extent of anthropogenic modification of landscapes - estimated as two-thirds of the Earth (Farina 2000) - conservation planning needs to incorporate ecosystem resilience and viability in relation to short- and long-term impacts.

In order to reveal the limitations of single perspectives and the benefits of holistic frameworks, this article evaluates two sets of perceived values for the flora and vegetation of the greater Lockerbie Scrub, an area of high conservation significance in far northern Queensland. The documented values under 'Western-style' state and national conservation planning are compared to those of its Indigenous owners. The overlap in values is assessed, and the implications for sustainable biodiversity conservation discussed.

\section{The greater Lockerbie Scrub}

The Lockerbie Scrub is an area dominated by tropical monsoonal rainforest in the Carnegie Range at the northern tip of Cape York Peninsula, northern Queensland. However, the rainforest boundaries are dynamic - being determined by edaphic conditions (i.e. soil and drainage), fire and clearing - and are interdigitated (i.e. there is a high boundary-to-area ratio) with other ecosystems of open Eucalyptus, Corymbia and Melaleuca-dominated sclerophyll forest and woodlands, mangroves, heathlands, coastal swamps and dune lakes. Thus, for socio-cultural, management and planning purposes, the rainforest communities are discussed within a broader landscape perspective as the greater Lockerbie Scrub.

The greater Lockerbie Scrub is owned and managed by the resident Aboriginal and Torres Strait Islander communities as Deed of Grant in Trust (DOGIT) land. ${ }^{4}$ Cultural expertise in relation to this area and its management is held by Traditional Owners, within cultural organisations such as the Gudang Corporation and Apudthama Land Trust. The boundaries of the Gudang and adjoining Traditional land owners cross the modern tenure and administrative boundaries of the DOGITs and regional councils (i.e. local government). The region is rich with archaeological sites (e.g. Greer 1995; McIntyre-Tamwoy 2000; McIntyre-Tamwoy \& Harrison 2004) and 'story places' used in socio-cultural education and interpersonal dynamics. It has significant cultural value to the local people due to their traditional, historical and ongoing relationship with their cultural landscape.

This area contains the northernmost extent of rainforest in Australia and has high biological significance. It has high species and ecosystem diversity due to the variety of rainforest types (Stanton \& Fell 2005) and sclerophyll vegetation, strong biogeographic links with rainforests in Papua New Guinea and north-eastern Australia, and numerous flora and fauna of national, state, regional and

\footnotetext{
${ }^{4}$ DOGIT land is a land tenure category under the Aboriginal Land Act 1991 (Qld) s. 13. It includes land granted in trust under the Land Act 1962 (Qld) for the benefit of Aboriginal inhabitants, as an Aboriginal reserve or subject to a lease under the Land Act 1962 or the Aborigines and Torres Strait Islanders (Land Holding) Act 1985 (Qld).
} 
Table 1 Summary of conservation significance of the greater Lockerbie Scrub area from regional studies (from Abrahams et al. 1995)

1. Contains a major occurrence of rainforest on the northern Peninsula.

2. Supports a significant representation of nationally rare semi-deciduous notophyll vine forest.

3. Approximately 60 per cent of the area supports regionally rare vegetation, predominantly notophyll vine forest and Eucalyptus novoguineensis woodland.

4. The biota displays an important biogeographic and evolutionary relationship to New Guinea.

5. A land-fall for migratory rainforest species crossing Torres Strait.

6. Supports a regionally rich collection of vegetation communities, which is likely also to contain a rich fauna.

7. Important habitat of rare and uncommon insects and endemic plant and animal species.

8. The type locality for numerous plant and animal species.

9. Supports a diverse orchid flora.

10 Contains a series of sand bars running parallel to Punsand Bay that form a sand bar platform representing amongst the best examples of this landform type in Australia.

11. A rich and diverse area of perennial waterbodies.
1992, NCA). Significance of regional ecosystems was based on current status (at 24 September 2010) under the Queensland Vegetation Management Act 1999 (VMA) using the Department of Environment and Resource Management's online Regional Ecosystem Description Database. ${ }^{7}$ The conservation status of regional ecosystems is based on the condition of remnant vegetation and the ratio of remnant to pre-clearing extent. local significance. Because of historical settlements and its proximity to early shipping routes, the region is also notable as the location of the type specimens associated with the naming of many species. The conservation and natural heritage values of the region were described in the Cape York Peninsula assessment by Abrahams et al. (1995; Table 1) and Mackey et al. (2001), and in its nomination for the Register of the National Estate (Montieth \& Joyce 1999).

\section{Methodology}

As part of a broader study of the history, environment, cultural relationships, conservation values, threatening processes and management requirements of the greater Lockerbie Scrub (Fell et al. 2009), information was compiled on threatened and other significant species and ecological communities within the area. This article reports on the flora and local vegetation types (termed in Queensland 'regional ecosystems'). ${ }^{5}$

The list of taxa in the area was derived from Queensland Herbarium records (the HerbRecs database), a defined area search of the EPBC Act Protected Matters search tool $^{6}$, site data from the study by Stanton and Fell (2005), supplemented by site data and field observations collected over six days during this study.

Conservation and cultural significance was tabulated for all taxa. Conservation significance for species was derived from current status on national (i.e. EPBC Act) and state legislation (i.e. Queensland Nature Conservation Act
Other values may be incorporated in Western conservation assessments, such as for the former Commonwealth Register of the National Estate and World Heritage List (e.g. disjunct taxa, taxa at edge of range, endemic taxa, monotypic taxa) and may be documented in development evaluations or environmental impact assessments. However, these categories generally lack legislative recognition under the EPBC Act and NCA, and tend not to be deterministic factors in environmental impact and development assessments; i.e. in evaluating 'triple bottom line' outcomes.

Cultural significance in the study was based on literature references to plant use specific to the area (MacGillivray 1852; Bryerley 1867; Moore 1974) and from oral testimony during visits to the area guided by Traditional Owners. Cultural significance was defined as significance to Aboriginal and Torres Strait Islander people based upon traditional, historical or contemporary use for food, medicine, materials, cultural and spiritual purposes, and as indicators of seasonal land and marine resource availability. The cultural values of local species were recorded in field notes during six days of fieldwork with four male Traditional Owners, including a community elder, and augmented through an historic literature review.

Nevertheless, Indigenous people do not necessarily differentiate between individual species, and the significance of plants, animals and objects cannot always

\footnotetext{
${ }^{5}$ Regional ecosystems represent vegetation communities that occur within a bioregion and are consistently associated with a particular combination of geology, landform and soil (Sattler \& Williams 1999).

${ }^{6}$ See http://www.environment.gov.au/erin/ert/epbc/index.html.

${ }^{7}$ See http://www.derm.qld.gov.au/wildlife-ecosystems/biodiversity/regional_ecosystems/index.php.
} 
be defined separately from their environmental and sociocultural context. In this case, the cultural significance of the Lockerbie Scrub lies in the important cosmological role of the forest and its spirit inhabitants, and not specifically in the assemblage of individual plant and animal species. It is also important that this study represented a preliminary effort to document cultural significance of local species, whereas the list of biologically significant plant species was based on 165 years of records (Jukes 1847; MacGillivray 1852; Brass 1953; Taylor 1972; Monteith 1974, 1987; Stanton 1976; Webb and Tracey 1981; Lavarack \& Godwin 1987; Grant \& Leung 1994; Roberts 1994; Abrahams et al. 1995; Neldner \& Clarkson 1995; Monteith \& Joyce 1999; Landsberg \& Clarkson 2004; Stanton \& Fell 2005). Thus, some plants were identified as having known cultural significance whereas others were of suspected or potential use in the area or in other parts of northern Australia, Papua New Guinea, the Pacific and Asia.

\section{Results - flora and vegetation values}

\section{Conservation significance}

The known flora for the greater Lockerbie Scrub comprised 1099 vascular plant species, with 99 of these naturalised or doubtfully naturalised. Of the 1000 native species, 37 (3.7 per cent) were identified as of

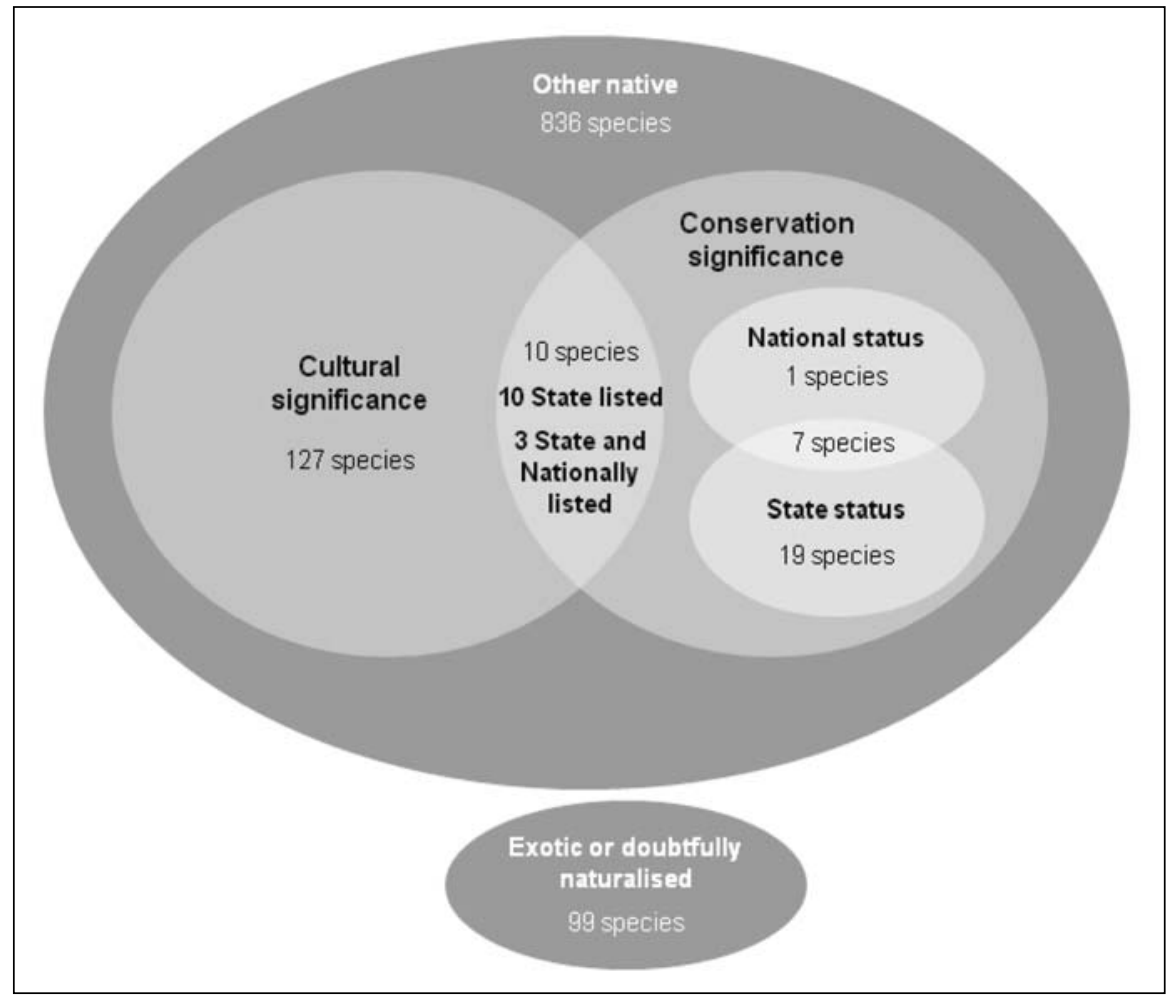

Figure 1 Proportions of the $\mathbf{1 0 0 0}$ native and 99 non-native flora in the greater Lockerbie Scrub recognised as of cultural or conservation significance conservation significance (Figure 1). Thirty-six species were listed as threatened or near threatened on state legislation and 11 as threatened on national legislation, with ten of these species listed under both legislative mechanisms.

Mapping of vegetation indicated that the greater Lockerbie Scrub contains 18 of the 30 Broad Vegetation Groups (i.e. subformations) and 29 of the 201 regional ecosystems that occur in the Cape York Peninsula bioregion (Table 2; Fell et al. 2009). Of these 29 regional ecosystems, 13 (44.8 per cent) had the conservation status 'of concern' under the VMA; i.e. their extent was 10-30 per cent of their pre-clearing extent across the bioregion and their remnant area totalled less than 10000 hectares but remained unaffected by moderate degradation or biodiversity loss. The vegetation types of conservation concern included types of rainforest, open forest and woodlands, grasslands and heaths (Table 2).

\section{Cultural significance}

Cultural significance to the local Indigenous people was identified for 137 native plant species (13.7 per cent of total native plants) and eight non-native plants. The known or potential significance of these species was primarily for food or material purposes (Table 3). The material uses included for timber and bark, firewood, decoration (using seeds or leaves), canoe-making, spear-making, garden transplants, sanding and cutting, lining earth ovens, pig and cattle fodder, fish poisons, and for constructing shelter, rattles, colonial matchboxes and clothes pegs, drums, pillows, cups (using leaves), cane chairs and baskets, rope, dye, mats, sails and bags (see Fell et al. 2009). The majority of these 145 native and non-native plants were trees (50 per cent) and shrubs (25 per cent). Notably, while the majority of culturally significant native taxa $(\mathrm{N}=137,73$ per cent) were from rainforest ecosystems, almost all of the eight naturalised culturally significant taxa were from non-rainforest ecosystems. This suggests a dynamism (i.e. relative invasiveness) within nonrainforest assemblages and within traditional practices (i.e. adaptiveness) of Indigenous people.

No cultural values were identified for particular vegetation communities per 
Table 2 The Broad Vegetation Groups in the greater Lockerbie Scrub with the number of total regional ecosystems in the region and those significant under the Vegetation Management Act 1999 (Qld)

\begin{tabular}{lccl}
\hline $\begin{array}{l}\text { Broad Vegetation Group } \\
\text { (structural type) }\end{array}$ & $\begin{array}{c}\text { No. of } \\
\text { BVGs }\end{array}$ & $\begin{array}{c}\text { No. of } \\
\text { regional } \\
\text { ecosystems }\end{array}$ & $\begin{array}{l}\text { No. and codes of significant } \\
\text { regional ecosystems* }\end{array}$ \\
\hline $\begin{array}{l}\text { Closed forest - rainforests } \\
\begin{array}{l}\text { Open forests and } \\
\text { woodlands }\end{array}\end{array}$ & 3 & 7 & $4-3.2 .1,3.3 .4,3.5 .3,3.12 .20$ \\
Grasslands & 3 & 7 & $4-3.2 .8,3.5 .5,3.5 .17,3.5 .23$ \\
Heaths & 1 & 6 & $2-3.5 .30,3.12 .31$ \\
Littoral vegetation & 1 & 1 & $2-3.2 .17,3.2 .33$ \\
Closed forest - mangroves & 1 & 2 & \\
Sedgelands & 1 & 1 & \\
Other vegetation & 2 & 2 & \\
\hline
\end{tabular}

* Significant as 'of concern' under the Act; ecosystem codes as in the Regional Ecosystem Description Database (Department of Environment and Resource Management)

se of the greater Lockerbie Scrub, although the biological values of the area are enmeshed within a socio-cultural landscape with a complexity of cultural, spiritual, medicinal and other resource use, and, traditionally, a seasonal way of life (Fell et al. 2009). From studies in the Lockerbie Scrub area of more general cultural heritage values (e.g Greer 1995; McIntyre-Tamwoy 2000), it can be inferred that closed forests and rainforests correspond to areas of high cosmological activity while open forests, woodlands and heath are safer landscapes and important hunting grounds. Similarly littoral vegetation zones especially dune forests - are important sources of forest fruits and yams (although in this region some of these

Table 3 Lifeform and uses of culturally significant flora according to status as native or nonnative, conservation listing or lack of conservation status

\begin{tabular}{|c|c|c|c|c|c|c|}
\hline & Lifeform ${ }^{1}$ & Food & Material & Medicinal & $\begin{array}{l}\text { Cultural/ } \\
\text { spiritual }\end{array}$ & Toxic \\
\hline \multicolumn{7}{|l|}{ Naturalised taxa } \\
\hline Rainforest/ vine thickets $(\mathrm{N}=1)$ & $1 \mathrm{~V}$ & 1 & 0 & 0 & 0 & 0 \\
\hline Other ecosystems $(\mathrm{N}=7)$ & $6 \mathrm{~S}, 1 \mathrm{~V}$ & 3 & 3 & 1 & 0 & 0 \\
\hline \multicolumn{7}{|l|}{ EPBC Act and NCA taxa } \\
\hline Rainforest/ vine thickets $(\mathrm{N}=3)$ & $1 \mathrm{~T}, 1 \mathrm{~S}, 1 \mathrm{P}$ & 2 & 2 & 0 & 0 & 0 \\
\hline Other ecosystems $(\mathrm{N}=0)$ & 0 & 0 & 0 & 0 & 0 & 0 \\
\hline \multicolumn{7}{|l|}{ NCA only taxa } \\
\hline Rainforest/ vine thickets $(\mathrm{N}=6)$ & $3 \mathrm{~T}, 1 \mathrm{P}, 1 \mathrm{~V}, 1 \mathrm{G}$ & 3 & 3 & 1 & 0 & 0 \\
\hline Other ecosystems $(\mathrm{N}=1)$ & $1 \mathrm{C}$ & 1 & 1 & 0 & 1 & 0 \\
\hline \multicolumn{7}{|l|}{ Other taxa } \\
\hline Rainforest/ vine thickets $(\mathrm{N}=91)$ & $\begin{array}{c}50 \mathrm{~T}, 18 \mathrm{~S}, 11 \mathrm{P} \\
8 \mathrm{~V}, 3 \mathrm{H}, 1 \mathrm{G}\end{array}$ & 46 & 45 & 9 & 8 & 8 \\
\hline Other ecosystems $(\mathrm{N}=36)$ & $\begin{array}{c}19 \mathrm{~T}, 11 \mathrm{~S}, 1 \mathrm{P} \\
1 \mathrm{~V}, 2 \mathrm{H}, 2 \mathrm{G}\end{array}$ & 13 & 22 & 3 & 2 & 3 \\
\hline Total & & 69 & 76 & 14 & 11 & 11 \\
\hline
\end{tabular}

${ }^{1} \mathrm{~T}=$ tree, $\mathrm{S}=$ shrub, $\mathrm{P}=$ palm, $\mathrm{C}=$ cycad, $\mathrm{V}=$ vine, $\mathrm{H}=$ herb, $\mathrm{G}=$ graminoid forests are also considered sentient), while mangroves are important resource areas for fish and shellfish.

The controlled, localised use of fire as a management tool was central to traditional resource use: to 'clean the country', maintain access through dense vegetation, to access plant and animal resources (e.g. honey trees, particular tree species for canoes and other implements), stimulate seasonal growth of food plants, and to create fire-breaks around camps and other important places (Fell et al. 2009). However, the region is also a 'dangerous' place with the rainforest vegetation inhabited by mischievous spirits. Behaviour in the rainforest is culturally prescribed and there is a requirement to act appropriately. This includes having local language skills or, for visitors, being always accompanied by local language speakers to ensure safe passage through the landscape; behaving in a restrained manner in terms of noise; not expressing expletives; not depleting resources; and leaving offerings for the forest guardian spirits (Fell et al. 2009).

\section{Comparison of values}

Only ten of the species (one per cent of the total native species) with cultural significance were also of conservation significance from a scientific perspective at state or national level (Figure 1). However, because this was a preliminary study of cultural values, more detailed investigation is warranted before firm conclusions should be reached on the coincidence of scientific and Indigenous cultural values.

The ten species identified as significant from both perspectives (Table 4) were primarily rainforest species of various lifeforms. All had food, material or medicinal value to the local Indigenous people, and all were threatened by multiple factors.

In relation to vegetation communities, the Traditional Owners of the greater Lockerbie Scrub were not specifically 
asked about particular vegetation communities at the level described by Western scientific vegetation mapping, so no comparison of vegetation community level values can be made at this time. However, it is important to note that the Traditional Owners perceive particular biota (and hence their values) within a landscape context.

\section{Discussion}

\section{Overlap in 'values'}

The minimal overlap between the lists of valued flora highlights the divergent perspectives underlying Western and Indigenous attitudes to flora conservation management, at least in the greater Lockerbie Scrub area. The disparity arises from the implementation of the underlying paradigms, since both Western and Indigenous perspectives claim to be holistic in basis.

The Convention on Biological Diversity aims to conserve the variability among living organisms from all sources and the ecological complexes of which they are part. The

Table 4 The ten species of conservation and cultural significance, with their status, lifeform, possible uses and potential threats (adapted from Fell et al. 2009)

\begin{tabular}{|c|c|c|c|c|c|c|c|c|c|c|c|}
\hline \multirow[t]{2}{*}{ Species } & \multicolumn{2}{|c|}{ Status* } & \multirow[t]{2}{*}{ Lifeform } & \multirow{2}{*}{$\begin{array}{l}\text { Rainforest/ } \\
\text { vine thicket } \\
\text { occurrence }\end{array}$} & \multirow[t]{2}{*}{ Cultural use } & \multicolumn{6}{|c|}{ Threats } \\
\hline & $\begin{array}{c}\text { EPBC } \\
\text { Act }\end{array}$ & $\mathrm{NCA}$ & & & & 冚 & $\frac{n}{3}$ & 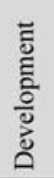 & $\frac{\frac{60}{2}}{\frac{5}{2}}$ & 莺 & $\frac{\mathscr{\varrho}}{\text { 氖 }}$ \\
\hline $\begin{array}{l}\text { Calamus aruensis } \\
\text { Becc. }\end{array}$ & & NT & vine & $\mathrm{X}$ & Materials & $\mathrm{X}$ & $\mathrm{X}$ & $\mathrm{X}$ & & & $X$ \\
\hline $\begin{array}{l}\text { Calophyllum } \\
\text { bicolor P.F.Stevens }\end{array}$ & $\mathrm{V}$ & V & shrub & $\mathrm{X}$ & Materials & $\mathrm{X}$ & $\mathrm{X}$ & & $\mathrm{X}$ & & $\mathrm{X}$ \\
\hline $\begin{array}{l}\text { Cycas semota } \\
\text { K.D.Hill }\end{array}$ & & $\mathrm{E}$ & cycad & & Materials, food & $\mathrm{X}$ & $\mathrm{X}$ & $\mathrm{X}$ & & $\mathrm{X}$ & $\mathrm{X}$ \\
\hline $\begin{array}{l}\text { Hydriastele costata } \\
\text { F.M.Bailey }\end{array}$ & V & V & palm & $\mathrm{X}$ & Materials, food & $\mathrm{X}$ & $\mathrm{X}$ & $\mathrm{X}$ & $\mathrm{X}$ & & \\
\hline $\begin{array}{l}\text { Neololeba atra } \\
\text { (Lindl.) Widjaja }\end{array}$ & & NT & graminoid & $\mathrm{X}$ & Materials & $\mathrm{X}$ & $\mathrm{X}$ & $\mathrm{X}$ & & & \\
\hline $\begin{array}{l}\text { Pandamus zea } \\
\text { H.St.John }\end{array}$ & & NT & palm & $\mathrm{X}$ & Materials, food & $\mathrm{X}$ & $\mathrm{X}$ & $\mathrm{X}$ & $\mathrm{X}$ & & \\
\hline $\begin{array}{l}\text { Sterculia } \\
\text { shillinglawii } \\
\text { F.Muell. subsp. } \\
\text { shillinglawii }\end{array}$ & & NT & tree & $\mathrm{X}$ & Food & $\mathrm{X}$ & $\mathrm{X}$ & $\mathrm{X}$ & & & \\
\hline $\begin{array}{l}\text { Syzygium } \\
\text { buettnerianum } \\
\text { (K.Schum.) Nied. }\end{array}$ & & NT & tree & $\mathrm{X}$ & Food & $\mathrm{X}$ & $\mathrm{X}$ & $\mathrm{X}$ & & & \\
\hline $\begin{array}{l}\text { Syzygium } \\
\text { malaccense (L.) } \\
\text { Merr. \& L.M.Perry }\end{array}$ & & NT & tree & $X$ & $\begin{array}{l}\text { Food, medicinal } \\
\text { properties reported } \\
\text { elsewhere }\end{array}$ & $X$ & $\mathrm{X}$ & $X$ & & & \\
\hline $\begin{array}{l}\text { Syzygium velarum } \\
\text { B.Hyland }\end{array}$ & V & V & tree & $\mathrm{X}$ & Food & $\mathrm{X}$ & $\mathrm{X}$ & $\mathrm{X}$ & & & \\
\hline
\end{tabular}

*E - endangered, V - vulnerable, NT - near threatened science of ecology is also underlain by a holistic interpretation of landscapes, biota and human influence. However, conservation planning and legislation tends to prioritise particular aspects of biodiversity - such as threatened species and ecosystems, species richness and endemism - and many scientists tend to focus quantitatively and in detail on a few variables (Berkes 2009).

Indigenous knowledge incorporates a large number of qualitative variables within a holistic environmental understanding grounded in intimate, long-term socioecological relationships. The Aboriginal view of nature is intensely humanised where people trace their descent from ancestral beings and carry the responsibility of continuing their actions. Nevertheless, Strang (1997) described Aboriginal management as focused on indigenous resources rather than the imposed resources (e.g. cattle) of pastoralists. Such a distinction may be a matter of degree, as indicated by the hunting of feral pigs by Aboriginal people, and it is important to acknowledge

that Indigenous knowledge is in constant evolution (Berkes 2009). The adoption of 'new' resources (e.g. pigs, nonnative plant species) and technology (e.g. guns, vehicles, outboard motors) need not be interpreted as a detraction from the integrity of their approach but rather as a demonstration of its inherent resilience.

Indeed, Indigenous and Western knowledge systems are independently viable but complementary approaches that can provide greater understanding of complex environmental and management issues, particularly given the short timescales of most scientific studies. Since little commonality was found in this study in flora values, incorporation of both perspectives would be complementary. It 
would increase the number of species of management significance, the range of values being accommodated, and enhance the potential and need for Indigenous leadership in local land management, as well as awareness of extinction risk.

Protection of rare and threatened species is essential for maintaining biodiversity. Indigenous managers can provide detailed local environmental and historical knowledge within a paradigm embodying sustainable productivity and of caring for country, but may interpret species loss and extinction in complex, non-absolute ways (Bird Rose 1996). In contrast, spatio-temporal quantification of species and ecosystem dynamics is suited to scientific investigation. This is especially pertinent given that almost half of the ecosystems in the greater Lockerbie Scrub are listed as threatened.

Evaluation of local ecosystem-level values is warranted and may provide complementary landscape perspectives. Indigenous values of vegetation types were not recorded by Fell et al. (2009). The Gudang participants in the study may not have related these values to the authors as they perceived the study to be focused on species, species' habitats and threatening processes, rather than including habitats or ecosystems explicitly.

However, while Jackson (2005) found that particular places or sacred sites only become foci when resources or places are under pressure or threat, Baker and Mutitjulu Community (1992) found that Indigenous Anangu and scientists that used a land systems classification classified landscapes in similar ways and with similar numbers of habitat components. Similarly, species-level comparisons of reptiles resulted in considerable overlap in identified species, but also considerable variation in which species were identified (Baker \& Mutitjulu Community 1992). In addition, the Anangu had knowledge of local environmental variability and biotic responses going back to a severe 1930s drought, and a detailed understanding of species' life history and behaviour. Baker and Mutitjulu Community (1992) referred to similar compatibility of Indigenous and scientific landscape classifications being documented by Walsh (1990) in Western Australia, and by Stevenson (1985) in the Northern Territory and Cape York Peninsula.

\section{Towards integrated, holistic environmental management}

Resilience thinking and systems analysis techniques provide scope for accommodating environmental and socio-cultural complexities as part of improved natural resource management and decision-making approaches (e.g. Lynch in press). The embedding of Western values in environmental legislation necessitates the continued incorporation of these values in conservation assessments and decision-making.

The key issue is how well other cultural values can be incorporated, and ensuring that multicultural perspectives are accommodated, especially in areas owned or comanaged by Indigenous people with alternative management and community development priorities. The difficulty is that socio-cultural aspects and support for occupation, access and connection to land need to be simultaneously addressed with biodiversity management, particularly for local and Indigenous communities, to enable regional resilience (Hill et al. 2008; Altman et al. 2009; Rotarangi \& Russell 2009). Inherently, this approach aligns with that of Indigenous communities, for whom ecological issues tend to be interconnected with social, economic and spiritual aspects (Rotarangi \& Russell 2009). Innovative approaches (e.g. Hill et al. 2008) that recognise the importance of maintaining sustainable socio-cultural and environmental systems are needed, particularly in low agricultural productivity landscapes and for often-disadvantaged Indigenous societies.

Accommodation of these multiple perspectives should incorporate the differing innate values along with an inclusive role for Indigenous people in adaptive management practice development and implementation as part of the greater consideration of self-governance and land tenure rights and responsibilities. The recognition of historical as well as spiritual and traditional connection to land is pertinent in northern Cape York Peninsula, where there has been forced (i.e. by government) and voluntary movement (i.e. resettlement of Torres Strait Islanders) of people across the landscape.

There may be difficulties in managing tradeoffs in intercultural environmental policy development and decision-making given the necessity of balancing social, economic and cultural values with environmental objectives, particularly when social and environmental values may appear to be nebulous, subjective and lacking in market value (Jackson 2005). However, the first step is to understand and recognise the significance of different perspectives and value systems. It is also important to engage in the slow, iterative process of trust building, faith keeping and benefit sharing between Indigenous groups, scientists and managers - as well as other stakeholders - to build 'communities of learning' (Robson et al. 2009). Such relationships have developed in Canada to co-produce locally relevant knowledge for 
joint problem-solving on issues of resource management and planning, environmental monitoring, climate change, and conservation (Berkes 2009).

Language skills are key to an effective dialogue on complex and layered issues such as Indigenous understandings of environment and cosmology (Johannes 1981; Greer 1995, p. 195). 'Language' is one of the key facilitators and inhibitors in accessing local Aboriginal domains. While it may not be always possible to build into projects the time required to learn local languages, there is no doubt that, where there is, not only are Aboriginal people empowered in the study but the extent and nature of information exchanged is enhanced.

Another way of enhancing engagement and collaboration may be through joint discussion and management of threatening processes to the region's values. Gamba grass (Andropogon gayanus), for example, is an invasive weed with an increasing extent in northern Cape York Peninsula and is a potential threat to most ( 84 per cent) of the threatened species in the greater Lockerbie Scrub. This exotic grass markedly increases local fuel loads, fire intensity and flame height, and severely impacts native species and savannah ecosystems (Howard 2001; Harris 2008). Design and implementation of management protocols for issues such as weeds, fire management and infrastructure development can provide common ground for inter-cultural engagement as these issues affect both the Western view of biodiversity and Indigenous cultural values. They also overlap with other values, such as protection of life and property. Often, it is issues such as these - for which otherwise disparate groups share a common interest - that can form common ground where alternative perspectives can be reconciled. When nonIndigenous people go onto country to talk about issues such as gamba grass, a process is instigated in which values are identified and shared. Such a process was demonstrated for fire management in the Queensland Wet Tropics World Heritage Area, where Indigenous people and park managers were in agreement with the desire to maintain communities and species populations but a social decision process was needed to mediate the groups' different goals (Hill et al. 1999).

Polarisation of attitudes towards information systems based on 'science' versus those derived from spiritual and socio-cultural relationships with nature can be realigned in recognition of the validity and necessity of accommodating multiple socio-cultural perspectives as part of long-term sustainability of all valued resources. Both Indigenous and Western environmental management approaches have impacted on landscapes and biotic assemblages, but both are relevant in building greater understanding and sustainability of environmental systems and their conservation needs.

\section{Acknowledgments}

The authors acknowledge comments on the manuscript by Janet Stephenson and an anonymous reviewer, assistance with Figure 1 by Bill Carter, and the collaboration in the study by Fell et al. (2009) of the Gudang Traditional Owners and the Apudthama Land Trust. They allowed access to the land and shared their knowledge of the region and its management issues. Since then, the Northern Peninsula Area Regional Council has established a new land and sea management program which incorporates a number of Traditional Owners into the ranger program. The original study was funded by the Australian Government under the Caring for Our Country program through the Queensland Department of Environment and Resource Management.

\section{References}

Abrahams, H, Mulvaney, M, Glasco, D \& Bugg, A 1995, Areas of conservation significance on Cape York Peninsula, report prepared by the Australian Heritage Commission \& the Environmental Resources Information Network for the Cape York Peninsula Land Use Study (CYPLUS), Australian Government Publishing Service, Canberra.

Agrawal, A 1995, 'Dismantling the divide between indigenous and scientific knowledge', Development and Change, vol. 26, pp. 413-439.

Altman, J, Kerins, S, Ens, E-J, Buchanan, G \& May, K 2009, Submission to the review of the National Biodiversity Strategy: Indigenous people's involvement in conserving Australia's biodiversity, CAEPR Topical Issue no. 08/2009, Centre for Aboriginal Economic Policy Research, ANU College of Arts and Social Sciences, Canberra.

Baker, LM \& Mutitjulu Community 1992, 'Comparing two views of the landscape: Aboriginal traditional ecological knowledge and modern scientific knowledge', Rangeland Journal, vol. 14, no. 2, pp. 174-189.

Beeton, RJS \& McGrath, C 2009, 'Developing an approach to the listing of ecological communities to achieve conservation outcomes', The Australasian Journal of Natural Resources Law and Policy, vol. 13, no. 1, pp. 61-91.

Berkes, F 2009, 'Indigenous ways of knowing and the study of environmental change', Journal of the Royal Society of New Zealand, vol. 39, no. 4, pp. 151-156.

Berkes, F, Golding, J \& Folke, C 2000, 'Rediscovery of traditional ecological knowledge as adaptive management', Ecological Applications, vol. 10, no. 5, pp. 1251-1262.

Bird Rose, D 1996, Nourishing terrains. Australian Aboriginal views of landscape and wilderness, Australian Heritage Commission, Canberra. 
Bowman, DMJS 1998, 'The impact of Aboriginal landscape burning on the Australian biota', Tansley Review no. 101, New Phytologist, vol. 140, pp. 385-410.

Brass, LJ 1953, 'Results of the Archbold Expeditions. No. 68. Summary of the 1948 Cape York (Australia) expedition', Bulletin of the American Museum of Natural History, vol. 102, pp. 135-206.

Briggs, JD \& Leigh, JH 1996, Rare or threatened Australian plants, CSIRO, Collingwood, Victoria.

Bryerley, FJ 1867, Jardines Journal: Narrative of the Overland Expedition of the Jardine Brothers from Rockhampton to Cape York, J.W Buxton, Brisbane. Facsimile edition, Corkwood Press, nd.

Butchart, SHM, Walpole, M, Collen, B, van Strien, A, Scharlemann, JPW, Almond, REA, Baillie, JEM, Bomhard, B, Brown, C, Bruno, J, Carpenter, KE, Carr, GM, Chanson, J, Chenery, AM, Csirke, J, Davidson, NC, Dentener, F, Foster, M, Galli, A, Galloway, JN, Genovesi, P, Gregory, RD, Hockings, M, Kapos, V, Lamarque, J-F, Leverington, F, Loh, J, McGeoch, MA, McRae, L, Minasyan, A, Hernández Morcillo, M, Oldfield, TEE, Pauly, D, Quader, S, Revenga, C, Sauer, JR, Skolnik, B, Spear, D, Stanwell-Smith, D, Stuart, SN, Symes, A, Tierney, M, Tyrrell, TD, Vié, J-C \& Watson, R 2010, 'Global biodiversity: indicators of recent declines', Science, vol. 328, pp. 1164-1168.

Chapman, AD 2009, Numbers of living species in Australia and the World, 2nd edition, Department of the Environment, Water, Heritage and the Arts, Canberra.

CoA (Commonwealth of Australia) 1992, The national forest policy statement, Australian Government Publishing Service, Canberra.

Cork, S, Sattler, P \& Alexandra, J 2006, 'Biodiversity', theme commentary prepared for the 2006 Australian State of the Environment Committee, Department of the Environment and Heritage, Canberra, viewed 3 June 2010, <http://www.deh.gov. $\mathrm{au} /$ soe/2006/commentaries/biodiversity/index.html>.

DERM (Department of Environment and Resource Management) 2010, Land transfers and claims, DERM, Brisbane, viewed 22 October 2010, <www.derm.qld.gov.au/ nativetitle/land/land_transfers_claims.htm $>$.

DEST (Department of the Environment, Sport and Territories) 1996, The national strategy for the conservation of Australia's biological diversity, DEST, Canberra.

DEWR (Department of Environment and Water Resources) 2007, Growing up strong: the first 10 years of Indigenous Protected Areas in Australia, DEWR, Canberra, viewed 22 October 2010, <http://www.environment.gov.au/indigenous/ publications/pubs/ipa-growing-up-strong.pdf $>$.

Easterling, DR, Meehl, GA, Parmesan, C, Changnon, SA, Karl, TR \& Mearns, LO 2000, 'Climate extremes: observations, modeling, and impacts’, Science, vol. 289, pp. 2068-2074.

Farina, A 2000, 'The cultural landscape as a model for the integration of ecology and economics', Bioscience, vol. 50, pp. 313-320.
Fell, DG, Lifu, M, McIntyre-Tamwoy, S, Roberts, C, Lynch, AJJ, Leung, L, Charlie, B \& Lifu, T 2009, 'Significant species and habitats of greater Lockerbie Scrub, Cape York Peninsula, Queensland', unpublished report to the Queensland Government Department of Environment and Resource Management, Brisbane.

Grant, JD \& Leung, L 1994, 'Storm season terrestrial fauna survey of the Lockerbie Scrub, Cape York Peninsula February 1994', unpublished report to the Queensland Department of Environment and Heritage, Cairns, Queensland.

Greer, S 1995, 'The accidental heritage: archaeology and identity in northern Cape York', PhD thesis, Department of Anthropology and Archaeology, James Cook University, Townsville, Queensland.

Harris, W 2008, 'Gamba grass (Andropogon gayanus Kunth.) a newly declared Class 2 plant in Queensland', Weed Spotters Newsletter, no. 11, pp. 1-3.

Hill, R, Baird, A \& Buchanan, D 1999, 'Aborigines and fire in the Wet Tropics of Queensland, Australia: ecosystem management across cultures', Society and Natural Resources, vol. 12, pp. 205-223.

Hill, R, Harding, EK, Edwards, D, O’Dempsey, J, Hill, D, Martin, A \& McIntyre-Tamwoy, S 2008, A cultural and conservation economy for northern Australia. A proof-ofconcept study, Land \& Water Australia, Canberra.

Howard, T 2001, 'Exotic grasses and fire', in R Dyer, P Jacklyn, I Partridge, J Russell-Smith \& D Williams (eds), Savanna burning: understanding and using fire in northern Australia, Tropical Savannas CRC, Darwin, p. 21.

Huntington, HP 2000, 'Using traditional ecological knowledge in science: methods and applications', Ecological Applications, vol. 10 , no. 5, pp. 1270-1274.

Indigenous Land Corporation (ILC) 2010, Land purchased, ILC, Adelaide, viewed 22 October 2010, <www.ilc.gov.au/ site/page.cfm? $\mathrm{u}=160>$.

IUCN (International Union for Conservation of Nature) 2001, IUCN Red List categories and criteria: Version 3.1, IUCN Species Survival Commission, IUCN, Gland, Switzerland.

Jackson, S 2005, 'Indigenous values and water resource management: a case study from the Northern Territory', Australasian Journal of Environmental Management, vol. 12, pp. 136-146.

Johannes, RE 1981, Words of the lagoon: fishing and marine lore in the Palau district of Micronesia, University of California Press, Berkeley, California.

Johnson, C 2006, Australia's mammal extinctions: a 50000 year history, Cambridge University Press, New York.

Jukes JB 1847, Narrative of the surveying voyage of HMS Fly, commanded by Captain FP Blackwood, in Torres Strait, New Guinea and other islands of the Eastern Archipelago, during the years 1842-1846: together with an excursion into the interior of the eastern part of Java, T \& W Boone, London.

Landsberg, J \& Clarkson, J 2004, Threatened plants of Cape York Peninsula, Queensland Parks and Wildlife Service, Environmental Protection Agency, Atherton, Queensland. 
Lavarack, PS \& Godwin, M 1987, 'Rainforests of northern Cape York Peninsula', in GL Werren \& AP Kershaw (eds), The rainforest legacy, vol. 1, Australian Heritage Publication Series no. 7 (1), Australian Government Publishing Service, Canberra, pp. 201-222.

Lewis, HT 1989, 'Ecological and technological knowledge of fire: Aborigines versus park rangers in northern Australia', American Anthropologist, vol. 91, no. 4, pp. 940-961.

Lynch, AJJ in press, 'The usefulness of a threat and disturbance categorization developed for Queensland wetlands to environmental management, monitoring and evaluation', Environmental Management.

MacGillivray, J 1852, Narrative of the voyage of the HMS Rattlesnake commanded by the late Captain Owen Stanley; RRS $\& c$ during the years 1846-50. Including discoveries and surveys in New Guinea, the Louisiade Archipelago, etc. To which is added the account of Mr E.B Kennedy's expedition for the exploration of Cape York Peninsula, 2 vols, facsimile edition by the Libraries Board of South Australia, Adelaide 1967 [original 1852: Boone, London].

Mackey, BG, Nix, H \& Hitchcock, P 2001, The natural heritage significance of Cape York Peninsula, Anutech Pty Ltd, Canberra.

McCarty, JP 2001, 'Ecological consequences of recent climate change', Conservation Biology, vol. 15, no. 2, pp. 320-331.

McIntyre-Tamwoy, S 2000, 'Red devils and white men: the shared heritage of Cape York', PhD thesis, School of Archaeology, Anthropology and Sociology, James Cook University, Townsville, Queensland.

McIntyre-Tamwoy, S \& Harrison, R 2004, 'Monuments to colonialism? Stone arrangements, tourist cairns and turtle magic at Evans Bay, Cape York', Australian Archaeology, vol. 59, pp. 31-42.

McLean, IFG, Wight, AD \& Williams, G 1999, 'The role of legislation in conserving Europe's threatened species', Conservation Biology, vol. 13, no. 5, pp. 966-969.

MEA (Millennium Ecosystem Assessment) 2005, Ecosystems and human well-being: synthesis, Island Press, Washington DC.

Monteith, GB 1974, 'Focus on Cape York', unpublished report from the Fauna Subcommittee of the Entomological Society of Queensland, Brisbane.

Monteith, GB 1987, 'History of biological collecting at Cape York, Queensland, 1770-1970', Queensland Naturalist, vol. 28, no. 1-4, pp. 42-51.

Monteith, GB \& Joyce, KA 1999, 'Lockerbie Scrub. Nomination for Register of the National Estate', unpublished report, Queensland Museum, South Brisbane.

Moore, D 1974, 'The Australian-Papuan frontier at Cape York: a reconstruction of the ethnography of the peoples on mainland Cape York and the adjacent Torres Strait Islands, their interaction with each other, and their prehistory; incorporating unpublished documentary evidence and an archaeological survey of the area', vol. 1, PhD thesis, Department of Prehistory, University of New England, Armidale, New South Wales.
National Native Title Tribunal (NNTT) 2010, National perspective, NNTT, Canberra, viewed 22 October 2010 , <http://www.nntt.gov.au/Native-Title-In-Australia/ Pages/National-Perspective.aspx $>$.

Natural England 2010, Lost life: England's lost and threatened species, Natural England, Sheffield, UK, viewed 15 March 2010, <www.naturalengland.org.uk/publications>.

Neldner, VJ \& Clarkson, JR 1995, Vegetation survey and mapping of Cape York Peninsula, Cape York Peninsula Land Use Study (CYPLUS), Office of the Co-ordinator General and Department of Environment and Heritage, Government of Queensland, Brisbane.

Roberts, CR 1994, 'A scoping study on Injinoo Custodial land with a view to establishing a management plan for the area north of 12 degrees latitude, Cape York, Australia', unpublished report, Cairns, Queensland.

Robson, JP, Miller, AM, Idrobo, CJ, Burlando, C, Deutsch, N, Kocho-Schellenberg, J-E, Pengelly, RD \& Turnera, KL 2009, 'Building communities of learning: Indigenous ways of knowing in contemporary natural resources and environmental management', Journal of the Royal Society of New Zealand, vol. 39, no. 4, pp. 173-177.

Ross, A \& Pickering, K 2002, 'The politics of reintegrating Australian Aboriginal and American Indian Indigenous knowledge into resource management: the dynamics of resource appropriation and cultural revival', Human Ecology, vol. 30, no. 2, pp. 187-214.

Rotarangi, R \& Russell, D 2009, 'Social-ecological resilience thinking: can indigenous culture guide environmental management?', Journal of the Royal Society of New Zealand, vol. 39, no. 4, pp. 209-213.

Russell-Smith, J, Lucas, D, Gapindi, M, Gunbunuka, B, Kapirigi, N, Namingum, G, Lucas, K, Giuliani, P \& Chaloupka, G 1997, 'Aboriginal resource utilization and fire management practice in western Arnhem land, monsoonal northern Australia: notes for prehistory, lessons for the future', Human Ecology, vol. 25, no. 2, pp. 159-195.

Russell-Smith, J, Stanton, JP, Whitehead, PJ \& Edwards, A 2004, 'Rain forest invasion of eucalypt-dominated woodland savanna, Iron Range, north-eastern Australia: I. Successional processes', Journal of Biogeography, vol. 31, no. 8, pp. 1293-1303.

Sattler, PS \& Williams, RD 1999, The conservation status of Queensland's bioregional ecosystems, Environmental Protection Agency, Brisbane.

SCBD (Secretariat of the Convention on Biological Diversity) 2005, Handbook of the Convention on Biological Diversity including its Cartagena Protocol on Biosafety, 3rd edition, SCBD, Montreal, Canada, viewed 22 November 2010, $<$ http://www.cbd.int/doc/handbook/cbd-hb-all-en.pdf>.

Smallacombe, S, Davis, M \& Quiggin, R 2007, Scoping project on Aboriginal traditional knowledge, Desert Knowledge Cooperative Research Centre, Alice Springs, Northern Territory. 
Stanton, JP 1976, National parks for Cape York Peninsula, Australian Conservation Foundation, Canberra.

Stanton, P \& Fell, D 2005, The rainforests of Cape York Peninsula, Cooperative Research Centre for Tropical Rainforest Ecology and Management, Cairns, Queensland.

Steffen, W, Burbidge, AA, Hughes, L, Kitching, R, Lindenmayer, D, Musgrave, W, Stafford Smith, M \& Werner, PA 2010, Australia's biodiversity and climate change, CSIRO Publishing, Collingwood, Victoria.

Stevenson, PM 1985, 'Traditional Aboriginal resource management in the wet-dry tropics: Tiwi case study', Proceedings of the Ecological Society of Australia, vol. 13, pp. 309-315.

Strang, V 1997, Uncommon ground. Cultural landscapes and environmental values, Berg, Oxford.

Taylor, RW 1972, 'Biogeography of insects of New Guinea and Cape York Peninsula', in D Walker (ed.), Bridge and barrier: the natural and cultural history of Torres Strait, Research School of Pacific Studies, Publication BG/3, ANU Press, Canberra, pp. 213-230.

Walsh, FJ 1990, 'An ecological study of traditional Aboriginal use of 'country': Martu in the Great and Little Sandy Deserts, Western Australia', Proceedings of the Ecological Society of Australia, vol. 16, pp. 23-37.

Webb, LJ \& Tracey, JG 1981, 'Australian rainforests: patterns and change', in A Keast (ed.), Ecological biogeography of Australia, W Junk, The Hague, pp. 607-694. 